\title{
Gertruda DRELICHARZ
}

Uniwersytet Jagielloński

gertruda.drelicharz@interia.pl

\section{MOTYWY MEMORATYWNE DOKUMENTÓW KAZIMIERZA KONRADOWICA, KSIĘCIA KUJAWSKO-ŁĘCZYCKIEGO}

ABSTRACT Memorative Motives of Documents of Kazimierz Konradowic, Duke of Kujawy and Łęczyca

The article focuses on the ideological content presented in documents originated in the chancellery of Kazimierz Konradowic who was the duke of Łęczyca and Kujawy, regions of Poland, in the years 1230-1267. The subject of the analysis are memorative motives, i. e. motives concerning time, memory, oblivion, doubt as well as fragility of the terrestrial matters and the chance to stop the time lapse by asking the divinity for help and intercession. To this day, 71 documents issued in years 1233-1267 by duke Kazimierz have survived. Most of them abound in erudite philosophical and theological reflections about various aspects. This article represents the main part of them that are above-explained memorative motives.

KEYWORDS ideology, memorative motives, memory, history, Poland 


\section{WSTĘP}

Temat artykułu stanowią motywy memoratywne dokumentów księcia kujawsko-łęczyckiego Kazimierza Konradowica. Kazimierz Konradowic, książę kujawski i łęczycki, syn Konrada Mazowieckiego, między rokiem 1230 a 1231 zaczął panować samodzielnie na Kujawach, a później także w ziemi łęczyckiej'. Jego życie przepełnione było walkami politycznymi, początkowo za młodu u boku ojca, potem zaś w trakcie samodzielnych rządów, aż do śmierci w 1267 r. Dla nas jednak jest to przede wszystkim czas coraz wyrazistszego formowania się aparatu kancelaryjnego w różnych dzielnicach polskich. Kancelaria Kazimierza kujawsko-łęczyckiego jest bardzo dobrym tego przykładem, dlatego też warto badać wszelkie aspekty jej funkcjonowania.

Samo powstanie kancelarii książęcej na ziemiach polskich stanowi jedno z najmniej jasnych zagadnień polskiej dyplomatyki z racji bardzo szczupłego materiału źródłowego. Problem rozwoju kancelarii książęcej oraz jej udziału w sporządzaniu dyplomów również wywoływał rozbieżne stanowiska uczonych. Kancelaria Kazimierza kujawsko-łęczyckiego była przedmiotem rozpraw kilku badaczy na przełomie XIX i XX w. oraz w minionym stuleciu. Dotychczas historycy zajmowali się wspomnianą tematyką w charakterze wybiórczym, m.in. Oswald Balzer i Józef Matuszewski, a po II wojnie światowej Karol Maleczyński i Stella Maria Szacherska². Pierwszym wnikliwym studium była dopiero rozprawa Józefa Mitkowskiego wydana w 1968 r., w której tenże badacz podjął się całościowej analizy kancelarii Konradowica ${ }^{3}$. Poglądy są odmienne także wobec pytania, jakie było znaczenie prawne dokumentu książęcego, zanim powstała kancelaria królewska Władysława Łokietka .

Zob. J. Powierski, Wydzielenie Kujaw Kazimierzowi Konradowicowi (potowa 1230 r.), „Rocznik Łódzki” 1993, t. 40, s. 91-112. Autor popiera ustalenia Balzera, że Kazimierz w 1231 r. był już księciem kujawskim. Sam zawęża przekazanie Kujaw Kazimierzowi przez ojca na czas po styczniu 1230 a przed styczniem roku 1231. Datę tego wydarzenia precyzuje na czerwiec bądź lipiec $1230 \mathrm{r}$. Zob. także Książę Kazimierz Konradowic i Kujawy jego czasów, red. D. Karczewski, Kraków 2017.

2 O. Balzer, Genealogia Piastów, Poznań 1895; W. Dworzaczek, Genealogia, Warszawa 1959; K. Maleczyński, Zarys dyplomatyki polskiej wieków średnich, Wrocław 1951; S. M. Szacherska, Z dziejów kancelarii ksiażąt kujawskich w XIII wieku. D wa nieznane dokumenty szpetalskie, „Studia Źródłoznawcze” 1960 , t. 5, s. 1-23.

3 J.Mitkowski, Kancelaria Kazimierza Konradowicaksięcia kujawsko-tęczyckiego (1233-1267), Wrocław 1968. Zob. J. Grabowski, Kancelarie książęce na Mazowszu (XIII-XVI w.). Stan badań i perspektywy badawcze, [w:] Belliculum diplomaticum II Thorunense, red. W. Chorążyczewski, J. Tandecki, Toruń 2007, s. 153-169; W. Korta, Rola kulturalna średniowiecznej kancelarii, [w:] Studia z dziejów kultury $i$ ideologii ofiarowane Ewie Maleczyńskiej w 50. rocznice pracy dydaktycznej i naukowej, WrocławWarszawa-Kraków 1968, s. 63-78.

4 S. Kętrzyński, Zarys nauki o dokumencie polskim wieków średnich, Warszawa 1934, s. 135. Zdaniem S. Kętrzyńskiego, W. Semkowicza i R. Taubenschalga dokument książęcy ma moc prawną równą dowodowi świadków dopiero od połowy XIII w., zaś w przekonaniu K. Maleczyńskiego można uważać wszystkie dyplomy książęce za równoważne pełnoprawnemu świadectwu, wobec czego już w pierwszej połowie XIII w. można mówić o dokumentach dyspozytywnych. 
Kolejną ważną kwestią jest zakres wykonywanych przez kancelarię zadań, tudzież pełnione funkcje i definicja pojęcias.

Niewątpliwie ludźmi, którzy albo samodzielnie kształtowali, albo współkształtowali przekaz ideowy wypływający z dokumentów księcia, byli pracownicy kancelarii kujawskiej, a potem kujawsko-łęczyckiej Kazimierza Konradowica. Pierwszym jego kanclerzem, którego znamy ze źródeł, był Piotr, pełniący tę funkcję prawdopodobnie w latach 1239-1241. Po zagarnięciu przez Kazimierza w 1247 r. dzielnicy łęczyckiej jej kanclerzem został Wolimir (który we wspomnianej dzielnicy zajmował to stanowisko już za panowania Konrada Mazowieckiego). Wolimir był kanclerzem zapewne do września 1252 r. (do momentu objęcia przezeń biskupstwa włocławskiego). Zastąpił go na tym stanowisku Janusz, mianujący się od początku kanclerzem księcia (a nie jednej z dzielnic) od września 1252 r. do kwietnia 1258 r. (do momentu objęcia arcybiskupstwa gnieźnieńskiego $)^{6}$. Nowa osoba na mianowanym stanowisku zostaje powołana dopiero między 1263 a 1266 r. Zostaje nią Rafał, kapelan księcia od 1257 r. Z kolei funkcję podkanclerzego kujawskiego księcia pełnił Maurycy, od 1245 lub 1246 r. aż do 1262 r., kiedy to prawdopodobnie umiera. W dwóch dokumentach, z lat 1238 i 1242, wspominany jest jednak jeszcze podkanclerzy Marcin, w którym Mitkowski (przeciwnie do Maleczyńskiego) widział głównego twórcę kancelarii dzielnicy kujawskiej. Co do pisarzy, tj. notariuszy kancelarii Kazimierza Konradowica, wiemy jedynie o dwóch. Pierwszy to Jan, o którym informacja pojawia się tylko w 1246 r. Kolejnym był Józef wzmiankowany w źródłach z lat 1255-1261, i miał on zapewne związki z katedrą gnieźnieńską, jak udowodniła Szacherska7.

Zakres chronologiczny pracy wyznaczają lata 1233-1267. Z tego okresu pochodzą zachowane do dziś dokumenty Kazimierza Konradowica, których autentyczność nie budzi zastrzeżeń. Zakres terytorialny wytyczają granice dzielnicy kujawskiej wydzielonej Kazimierzowi przez ojca oraz łęczyckiej zagarniętej przez księcia po jego śmierci. Obecnie dysponujemy 71 dyplomami wymieniającymi Kazimierza Konradowica jako wystawcę (jednak niektóre przetrwały w kilku oryginalnych egzemplarzach - trzy w podwójnych, jeden w potrójnym - można mówić względnie o 76 dokumentach). Jeśli odejmiemy falsyfikaty, pod uwagę brać będziemy 68 dokumentów. Jest to proporcjonalnie o połowę mniej niż liczba dokumentów Przemysła I, których do dziś zachowało się 63 z okresu zaledwie 16 lat panowania (1242-1257). Trzeba jednak pamiętać, iż w Wielkopolsce warunki przechowywania źródeł materialnych były zazwyczaj lep-

Zob.F.Sikora,Zestudiównadśredniowiecznymikancelariamipolskimi, „Studia Historyczne” 1973, t. 16, s. 3-47; M. Bielińska, Kancelarie i dokumenty wielkopolskie XIII wieku, Wrocław-Warszawa-Kraków 1967; rec.: K. Maleczyński, „Śląski Kwartalnik Historyczny Sobótka” 1967, t. 22, s. 369-375; K. Jasiński, „Przegląd Historyczny” 1968, t. 59, s. 164-171; B. Kürbis, „Studia Źródłoznawcze” 1968, t. 13, s. 189-192; K. Mieszkowski, Najnowsze badania nad dyplomatyka wielkopolska XIII wieku, „Przegląd Historyczny” 1970, t. 41, s. 687-691 (całość: s. 684-695); Dyplomatyka staropolska, red. T. Jurek, Warszawa 2015.

6 Zob. F. Sikora, Janusz, kanclerz arcybiskupa Petki i księcia Kazimierza Konradowica (1232-1252 i 1252/53-1258), „Nasza Przeszłość” 1966, t 24.

Kwestię personelu kancelaryjnego księcia Konradowica i dyskusje uczonych wokół tego tematu zbiera J. Mitkowski. Zob. J. Mitkowski, Kancelaria..., s. 48-66. 
sze niż na Kujawach. Ponieważ dokumenty, których dotyczy artykuł, spisane zostały w języku łacińskim, w tekście głównym cytuję fragmenty przetłumaczone przez siebie, $\mathrm{w}$ przypisach zaś zamieszczam fragmenty w ich oryginalnym brzmieniu.

Dla większej klarowności przyjęłam dla dokumentów sygnatury, które numeruję w takiej kolejności, w jakiej uszeregował je przed pięćdziesięcioma laty Mitkowski; na ich początku stawiam literę $M$ od nazwiska wspomnianego badacza (rezygnuję ze słów „Reg. nr”). Wprowadzone sygnatury uważam za zasadne, gdyż pozwalają czytelnikowi uporządkować wspomniane dyplomy chronologicznie wobec panowania księcia Konradowica. Z kolei zapisywanie na ich początku litery M także jest mym zdaniem zrozumiałe, bowiem dopiero Mitkowski podją się trudu zebrania i uporządkowania wszystkich zachowanych dokumentów Kazimierza kujawsko-łęczyckiego. Niewykluczone, że gdyby nie on, do tej pory nie dysponowalibyśmy takim zestawieniem ${ }^{8}$.

Niniejszy artykuł stanowi pierwsze uporządkowanie dokumentów księcia Kazimierza Konradowica od strony ideowej i jedno z niewielu takich usystematyzowań dokumentów książąt dzielnicowych. Artykuł ten omawia jedynie część przekazu ideowego kancelarii Konradowica, gdyż w przeciwnym razie praca musiałaby być o wiele szersza. Zadania zebrania i uszeregowania areng, a niekiedy i innych formul dokumentów piastowskich z okresu rozbicia dzielnicowego, badacze polscy podejmują się od lat kilkudziesięciu. Do tej pory jednak nie dysponujemy wystarczającą liczbą dysertacji z podanej tematyki, a zwłaszcza zestawień areng piastowskich. Pewną pomocą dla badaczy są bazy dokumentów niemieckich i francuskich, ale bez opracowania historii personelu poszczególnych kancelarii polskich oraz stworzenia baz tychże polskich kancelarii poszukiwanie wzorców w ich obcych odpowiednikach jest błądzeniem we mgle. Nie jest odkryciem, iż sformułowania bliźniacze z tymi w dokumentach Konradowica odnajdziemy w dokumentach niemieckich (m.in. westfalskich) sto lat wcześniej. Pytanie stanowi to, jakimi drogami, poprzez jakich ludzi i teksty wzorce te dotarly na grunt polski. Owego pytania z kolei nie możemy zadać bez posiadania uszeregowanych własnych formuł, gdyż inaczej nie wiedzielibyśmy, czego szukać. Takiemu właśnie uszeregowaniu ma służyć niniejsza praca.

\section{ARENGA I INNE FORMUŁY NIOSĄCE TREŚCI IDEOWE}

Aby właściwie zademonstrować wszystkie pojawiające się w wybranych do analizy dokumentach motywy ideowe i przemawiające z nich główne myśli, przedstawię, jak literatura przedmiotu zapatruje się na kwestie arengi i pozostałych formuł, które niosły treści ideowe. $Z$ racji tego, że owo zagadnienie jest bardzo obszerne, sygnalizuję jedynie najważniejsze spostrzeżenia.

Arengę, zwaną inaczej preambułą, zwykło się definiować jako filozoficzno-teologiczne bądź etyczne uzasadnienie spisania dokumentu. Bardzo często definicję powyż-

Wykaz skrótów zastosowanych dla wydawnictw źródłowych oraz aneks zawierający dokładny adres wszystkich dokumentów Kazimierza Konradowica umieszczam na końcu artykułu. 
szą łączyło się dawniej z nieuzasadnionym bliżej założeniem schematyzmu i braku oryginalności tych sformułowań refleksyjnych? Przełomem w myśleniu o nich była praca Heinricha Fichtenau’a z 1957 r., który nie tylko swymi badaniami pozbawił podstaw zapatrywanie dotychczas dominujące w nauce, ale także wskazał arengę jako najistotniejsze miejsce dla propagandy władzy wystawcy dokumentu. Jego rozprawy do dzisiaj stanowią punkt wyjścia do wszelkich badań na temat warstwy ideowej strony wewnętrznej dyplomu ${ }^{10}$.

Preambuły nie powstawały w izolacji od teorii retorycznych, spuścizny po antyku żywej wśród elit intelektualnych w wiekach XIII i XIV. Wywiedzione bowiem ze starożytności „podręczniki dobrego przemawiania” stanowiły punkt odniesienia dla współczesnych, uważających się za spadkobierców i kontynuatorów poprzedniej epoki ${ }^{11}$. Ich wpływ na pisarstwo średniowieczne był przemożny, w szczególności jeśli chodzi o dzieła Marka Tulliusza. Wzorce antyczne były adaptowane do ówczesnych warunków przez tzw. artes dictaminis (dosłownie „sztuki przemawiania”), czyli teoretyczne traktaty o konstrukcji dokumentu. Uważa się, iż w tym czasie stanowiły one podporę tudzież uzasadnienie retoryczne dla struktury i roli, jaką pełniła arenga ${ }^{12}$. Przeważnie za miejsce narodzin podręczników poprawnego pisania uważa się klasztor Benedyktynów na Monte Cassino ${ }^{13}$. W dużym skrócie można powiedzieć, iż arenga pełni funkcję perswazyjną $^{14}$. Średniowieczne traktaty nie uwzględniają wszakże w ogóle wymowy ideologicznej, jaką formuła zaczęła pełnić w dokumencie.

Arenga właściwa dla uroczystych tekstów późnoantycznych, w średniowieczu pojawia się prawie stale, jednak funkcjonuje w różnych wariantach, w zależności od czasu i miejsca powstania arengi. W nowożytności nie zrezygnowano z preambuł, podobnie

9 Zob.Z. Perzanowski, Ze studiów nad arengą dokumentów Kazimierza Wielkiego, [w:] Historia i archiwistyka. Ksiega pamiątkowa ku czci prof. Andrzeja Tomczaka, Toruń-Warszawa 1992, s. 16-17 (zestawienie definicji arengi w podręcznikach polskiej dyplomatyki); A. Adamska, Arengi w dokumentach Wtadystawa Eokietka. Formy i funkcje, Kraków 1999, s. 16-17, przypisy 16-17 (poszerzenie informacji o literaturę najnowszą).

10 H. Fichtenau, Arenga. Spätantike und Mittelalter im Spiegel von Urkundenformeln, Graz-Köln 1957, s. 10; idem, Monarchische Propaganda in Urkunden, [w:] Beiträge zur Mediävistik. Ausgewählte Aufsätze. Allgemeine Geschichte, Bd. II, Stutgart 1977, s. 32; O. Guyotjeannin, J. Pycke et B.-M. Tock, Diplomatique médiévale, Turnhout 1993, passim.

11 Zob. S. Barret et B. Grévin, Regalis excellentia. Les préambules des actes des rois de France au XIVe siècle (1300-1380), s. 94-95.

12 C. Vulliez, L'apprentissage de la rédaction des documents diplomatiques à travers l’ars dictaminis français (et spécialement ligérien) du XIIe siècle, [w:] Cancelleria e cultura nel medio evo, Città del Vaticano 1990, s. 76-95; F. J. Worstbrock, Die Antikenrezeption in der mittelalterlichen und der humanistischen Ars Dictandi, [w:] Die Rezeption der Antike. Zum Problem de Kontinuität zwischen Mittelalter und Renaissance, red. A. Buck, Hamburg 1981, s. 15-24; H. Fichtenau, Arenga..., s. 161-162.

13 J. Murphy, Rhetoric in the Middle Ages, Berkeley-Los Angeles-London 1974, s. 203 i n.

14 Zob. A. Adamska, Arengi..., s. 115, przyp. 11; określenie „funkcja perswazyjna” zaproponowane przez M. Korolkę: M. Korolko, Z badań nad retorycznościąpolskich kronik średniowiecznych (ethopoiia - sermocinatio - fikcyjna mowa), [w:] Literatura i kultura późnego średniowiecza w Polsce, red. T. Michałowska, Warszawa 1993, s. 128 i n. 
jak i dzisiaj ${ }^{15}$. Według Michela Zimmermanna te formuły jako elementy w aparacie dyplomatycznym nadprogramowe, z pozoru „zbędne”, zdobiące ręką notariuszy w sposób swobodny dokumenty, miały za cel demonstrować ich umiejętności i sprawność literacką $^{16}$. Wiele areng wyróżnia się bogactwem metafor, szykiem i długością, przez co zajmują one w dyplomie główne miejsce. Zatem nie można ich określić mianem bezużytecznych bądź stanowiących naddatek; przeciwnie, nawet stwierdzenia takie jak "dlatego”, „stąd też”, „dlatego więc” czy inne nie bez przyczyny wplecione są w ich treść, gdyż spajają preambuły z resztą tekstu. Poza walorami estetycznymi liczyła się przy redakcji arengi również umiejętność postępowania zgodnie z zasadami kompozycji retorycznej, aby móc osiągnąć doskonałość artystyczną. Pamięć o tym, z jaką pieczołowitością przestrzegano zasad retorycznych, jest warunkiem koniecznym dla zrozumienia prawideł redakcji średniowiecznych pism oficjalnych. W średniowieczu dokument rozumiano zarówno jako świadectwo działań prawnych, jak i dzieło literackie ${ }^{17}$. Arenga zatem miała wedle zamierzenia redaktorów zdobić dyplom; w niej pisarze mogli dać upust erudycji i umiejętnościom kompozycyjnym. Na pierwszym miejscu stawiano jasność wypowiedzi, zgodnie ze średniowiecznymi podręcznikami dobrego przemawiania (summae dictaminis). Podręczniki te kładły nacisk na utrzymanie w dokumencie harmonii kompozycyjnej rozumianej jako efekt dopasowania wszystkich części do charakteru dyspozycji, która stanowiła centralny punkt dyplomu.

Nieraz i w innych miejscach dokumentów można znaleźć wspólne myśli z tymi, które zawarto właśnie w arengach, a niekiedy zdarzają się dyplomy pozbawione areng, które niosą podobne ideowo treści za pomocą zwrotów zawartych w innych formułach $^{18}$. Jakkolwiek preambuła zawsze pozostanie ideowo od strony wewnętrznej dokumentu centralnym jego punktem w warstwie ideowej, pamiętać należy, iż przekaz, w tym retoryczny i ideologiczny, zawarty jest od pierwszych do ostatnich słów, z których zbudowany jest dyplom. Zatem sformułowania nacechowane $w$ wielkim stopniu religijnie poza tymi najbardziej rozpowszechnionymi (jak inwokacja i aprekacja) pojawiały się także w promulgacjach i salutacjach, a określenia przedstawiające majestat wystawcy padały nieraz w narracjach (opisujących wypadki poprzedzające wystawienie dokumentu) oraz w dyspozycjach (stwierdzających o zaistniałym akcie prawnym jako uzasadnienie podjętej decyzji), często aby podkreślić autorytet wystawcy. Zwroty temporalne zazwyczaj znajdziemy i w arengach, i w korroboracjach, gdyż uwierzytelnienie na równi ze spisaniem dokonanych czynności stanowiło formę zapobieżenia złym skut-

15 Zob. S. Barret, B. Grévin, Regalis excellentia. Les préambules des actes des rois de France au XIV siècle (1300-1380), s. 96, przyp. 29, 38, 97.

16 M. Zimmermann, Protocoles et Préambules dans les documents Catalans du Xe au XII siècle. Évolution diplomatique et signification spirituelle. Les Protocoles, „Mélanges de la Casa de Velázquez” 1974, t. 10, s. 51 (całość: s. 41-76).

17 Stanisław Kuraś przewartościował nawet znaczenie dokumentu jako dzieła literackiego, pozbawiając go wagi jako aktu dyspozycyjnego, jednakże uznaje się to za przejście w drugą skrajność; zob. S. Kuraś, Przywileje prawa niemieckiego miast i wsi matopolskich XIV-XV wieku, Wrocław-Warszawa 1971.

18 Zob. T. Jurek, Stanowisko dokumentu w średniowiecznej Polsce, „Studia Źródłoznawcze” 2002, t. 40, s. $1-18$. 
kom upływu czasu, do których należało wykorzystywanie utraty dowodu zaistnienia jakiejś czynności prawnej przez osoby postronne. Pojawia się też często w dyplomie życzenie, aby podjęte postanowienia trwały przez wieki. Z kolei wyrażenie woli, aby istniały one trwale, czy też niewzruszenie, można zakwalifikować jako wyróżnione przez Zimmermana nawiązania do prawideł prawnych. W opisach złych i dobrych zachowań widzimy z kolei nie tylko odwołanie do dawnych wydarzeń, ale również nie wprost nazwane rozważania moralne, gdyż zazwyczaj możemy zauważyć, po której stronie staje autor. Maksymy prawnicze przekazywane są także w opowiadaniach o sprawiedliwości, jaką wykazał się wystawca dokumentu. Trudno zatem zdecydowanie oddzielić preambułę od pozostałych partii dyplomu, jak czyniono to w starszych podręcznikach dyplomatyki. Zwroty, które padają w różnych formułach, i przemawiające z nich myśli okazują się korespondować z pozostałymi partiami tekstu. Jawią się jako jedna silnie powiązana całość.

W średniowiecznej mentalności rezygnacja z przekazu retorycznego oraz wymogu zademonstrowania piękna wypowiedzi było nie do pomyślenia; oczywiste zatem, iż starano się spisywać formuly zawierające treści ideowe w sposób jak najbardziej kunsztowny i wyraziście objawiający erudycję ich autora. Dyplom odpowiednio przygotowany od strony retorycznej miał za zadanie nie tylko czytelnie ilustrować relację między wystawcą a odbiorcą dyplomu, a przede wszystkim misternie przedstawiać zasady moralne, prawne i religijne wyznawane przez wystawców i odbiorców. Kunszt pisarski notariuszy mógł za to niejednokrotnie mieć poważne znaczenie dla realizowanej działalności politycznej władców, którym służyli, a także dla zachowania bądź stworzenia autorytetu wśród sąsiadów i we własnych kręgach ${ }^{19}$.

Co wynikało z przekazywanych za pomocą ozdobnych formuł treści ideowych? Ze sformułowań oraz zwrotów retorycznych traktujących o prawidłach moralnych, prawnych i religijnych wyłaniać się miał obraz władcy-prawodawcy, monarchy sprawiedliwego, jak również pobożnego i hojnego, władcy-fundatora (princeps fundator) ${ }^{20}$. Wymienione przedstawienia przypominają obraz doskonałego imperatora rzymskiego - na którym ślad odcisnęło także chrześcijaństwo - ukazujący cesarza jako ucieleśnienie wszelkich cnót i postać regulującą wszystkie aspekty życia poddanych. Oddźwięk takiego pojmowania władcy i samej władzy widać od czasów Nowel Justyniana, inspirujących potomnych ${ }^{21}$. W interesie wystawców było przeznaczenie funkcji składających się na aparat kancelaryjny ludziom uczonym i świattym, aby ci przedstawili ich w sposób tak elokwentny, jak pozwalały owym odziedziczone po wcześniejszych twórcach teorie retoryczne oraz traktaty filozoficzne i prawnicze.

19 Zob. B.-M. Tock, Les textes diplomatixes, des médias au Moyen Âge?, [w:] Le rôle des médias à travers l'histoire, textes réunis et publiés par M. Serwański, Poznań 1995, s. 62-84.

20 Zob. R. Michałowski, Princeps fundator. Studium z dziejów kultury politycznej w Polsce X-XIII wieku, Warszawa 1993.

21 E. Kantorowicz, Dwa ciata króla, Warszawa 2007, s. 104; zob. cały rozdział: s. 72-156. 


\section{MOTYWY MEMORATYWNE DOKUMENTÓW KAZIMIERZA KONRADOWICA}

Motywy memoratywne dokumentów, jakie zamierzam przedstawić, zawarte zostały w erudycyjnych rozważaniach z pogranicza filozofii i teologii poruszających różne aspekty idei czasu. Są to tematy najczęściej poruszane w dokumentach księcia Kazimierza Konradowica. Czas postrzegany jest w nich jako jedno z najważniejszych prawideł dziejów, istotne ze względu na świadomość o jego niszczącym wpływie na wszystko, co mu podległe. Tzw. upadek rzeczy traktuje się w kategoriach nieuchronnej konieczności, jednakże zadaniem wystawcy jest odwleczenie nieubłaganej kolei rzeczy; ma on działać zapobiegawczo, podjęte decyzje deklaruje się jako stałe i niewzruszone. Monarcha pragnie niejako postawić się ponad czasem i jego zasadami. Najwięcej takich zwrotów zawiera najpopularniejszy nośnik treści ideowych, jakim są arengi, jednak okazałe metafory i figury pojawiają się również w korroboracjach (na drugim miejscu pod względem liczebności), narracjach i dyspozycjach dyplomów księcia Kazimierza. Kunsztownie skonstruowane rozważania albo odwołania w nich zawarte prowadzą do wniosku o konieczności spisania i uwierzytelnienia dokumentu, czym sugerują nieprzemijalność monarszych działań. Ich celem jest jednak przede wszystkim przechowanie pamięci o dokonanych czynach, stąd arengi zawierające tego typu rozważania określa się właśnie mianem memoratywnych ${ }^{22}$. Wyróżniłam pięć grup motywów, które przedstawiam poniżej.

\subsection{Znikomość świata i chwiejność czasu}

Na początku przedstawię fragmenty czterech areng, w których opisano problem zmiennych i złych czasów, znikomości świata i przewrotności ludzkiej natury.

\subsubsection{Upływ czasu}

Wspomnieć należy o czynniku leżącym u podłoża problemu zanikania i odchodzenia w niepamięć czynów ludzkich, jakim jest upływ czasu. Przez kancelistów ta prawidłowość była wielokrotnie przywoływana. Wszystkich zwrotów zawierających określenie „upływ czasu” pada w dokumentach 14 . Z tego 11 można znaleźć w arengach, pozostałe - w korroboracjach ${ }^{23}$.

Określenie „upływ czasu” (processus temporum) pada w prawie identycznie brzmiących zdaniach pięciu areng (z pewnymi obocznościami), w których próbę zapobieże-

22 O arengach memoratywnych książąt mazowieckich zob. T. Nowakowski, Idee areng dokumentów książat polskich do potowy XIII wieku, Bydgoszcz 1999, s. 147-180.

23 W arengach dokumentów o sygnaturach: M3, M13, M15, M17a, M19, M23, M24, M25, M53, M54; w korroboracjach dyplomów: M6, M34, M44, M65. W sytuacji gdy cytowana jest bardzo duża liczba dokumentów albo kilkakrotnie odwołuję się do tego samego, dla uniknięcia zakłóconego odbioru nie podaję za każdym razem miejsca ich wydania; dokładne informacje zawarte są w aneksie na końcu pracy. 
nia podległości czasowi czynów ludzkich ujęto w formie życzenia Aby czyny ludzkie nie ulegty zagtadzie przez uptyw czasu, potwierdza się je uroczystym zaświadczeniem pism²4. Preambuły w przytoczonym brzmieniu pojawiają się w pięciu dokumentach księcia z lat 1247, 1248, 1250 i 1257. Są to po kolei dyplomy dla rycerstwa, kapelana Marka, wojewody łęczyckiego Spicygniewa, braci Szpitala św. Jana, prepozyta włocławskiego i kapelana książęcego Mikołaja oraz dla augustianów ze Mstowa.

Co do pozostałych czterech areng, w dyplomie z Kruszwicy z 1233 r. wspomniano, iż czyny są potwierdzane pismem, aby podczas uptywu czasu pozostaty w pamięci. W dokumencie wystawionym w Inowłodzu na wiecu w grudniu 1249 r. dla cystersów jędrzejowskich mowa o tym, aby postanowienia nie zanikty w miarę uptywu czasu, zaś w aktach z Kramska z 15 sierpnia 1255 r. i z Kazimierza z 6 lutego 1261 r. dla cystersów sulejowskich padają zdania, iż w miarę uptywu czasu ubywa świadków, przez co czyny ludzkie nie moga być niczym potwierdzone ${ }^{25}$. Wyrażenie "upływ czasu” pada ponadto w dwu korroboracjach. W dokumencie z Kruszwicy z 13 stycznia 1238 r. oraz z 1265 r. mowa o tym, żeby „w miarę upływu czasu w czasie poczynione rzeczy nie popadły w otchłań niepamięci" oraz by podczas przemijania postanowienia nie śmiały być przez nikogo naruszone ${ }^{26}$.

Inne określenia padają w trzech arengach i jednej korroboracji. Najpierw w preambule dyplomu z Kowala z 9 września 1251 r. dla opata sulejowskiego Piotra: ponieważ w trakcie biegu czasu zte rozumienie rzeczy zwykto dotykać czynów ludzkich ${ }^{27}$. Następnie w akcie z 1251 r. dla biskupa krakowskiego Prandoty i z Łęczycy z 6 sierpnia 1260 r. dla arcybiskupa Janusza padają słowa: przez bieg czasu często zanikają dowody czynności prawnych $^{28}$. Ze wzmianką o przemijającym czasie mamy do czynienia w korroboracji dokumentu ze Zgłowiączki z 11 czerwca 1253 r. dla biskupa włocławskiego Wolimira;

24 M13 ar., Przypust, 1247: Ne res gestas aboleat processus temporum, confirmat illas sollempnis titulus litterarum...; M15 ar., Zgierz, 1248: [jak wyżej] sollempnis titulus literarum...; M19 ar., Kłobia, 10 VIII 1250: [jak wyżej] sollemnis titulus literarum...; M23 ar., 1250: [jak wyżej] sollempnis titulus litterarum...; M44 ar., 3 V 1257: [jak wyżej] solempnis tytulus literarum...

25 M3 ar., Kruszwica, 1233; KDP, t. II, nr 14, s. 11-12: ...ut, dum processu temporis a memoria recesserint, inspectione littere ad eandem reuocentur..; M17a ar., Inowłódz na wiecu, XII 1249. K. Maleczyński, Dwa nieznane dokumenty, „Kwartalnik Historyczny” 1924, t. XXXVIII, s. 456-459; ne... processu temporis euanescat...; M38 ar., Kramsko, 15 VIII 1255; KDP, t. II, nr 68, s. 56-58 i M54 ar., Kazimierz, 6 II 1261; KDP, t. 1, nr 49, s. 84-86: Licet acta hominum noticie subjaceant singulorum, processu tamen temporis, testibus deficientibus legitimis...

26 M6 korr., Kruszwica, w grodzie, 13 I 1238; KDP, t. II, nr 21, s. 16-17 (z bł.): Verum ne processu temporis res acta in tempore, sicut plerumque contigit uel solet contigere, in aluo obliuionis demergatur..; M65 korr., 1266; DKM, nr 35, s. 205-206: a nemine... processu temporis ualeat... disturbari...

27 M24 ar., Kowal, 9 IX 1251; KDP, t. I, nr 37, s. 58-60: Quoniam decursu temporis calumpnia consuevit actibus hominum novercari... Por. K. Maleczyński, Studya nad dyplomami i kancerlarya Odonica i Laskonogiego (1202-1239), Lwów 1928, m.in. s. 96-98 (przy zestawieniu dokumentów nr 152 i 218 arenga Quoniam omnia que temporaliter aguntur per decursionem temporis annulantur...).

28 M25 ar., Kowal, 1251; KDKk, t. I, nr 32, s. 40-41: Quoniam propter tractum temporis longeui sepius sufficencia deficit probacionis, et sic ueritas plerumque in dubium reuocatur..; M53 ar., Łęczyca, 3 VIII 1260; KDW, t. I, nr 388, s. 343-344: Quoniam propter tractum temporis longevi sepius deficit sufficiencia probacionis... 
wspomniano tam, aby $w$ trakcie przemijajacego, przechodzacego czasu przez nikogo kosciót nie byt nękany ${ }^{29}$.

\subsubsection{Niestałość, chwiejność czasu}

W preambule dyplomu z Kruszwicy z 13 stycznia 1238 r. poruszono wątek chwiejności czasu, przeciw której działając, jak również przeciw uptywowi rzeczy czasowych należy to, co czasowe, powierzyć pamięci $i^{30}$.

\subsubsection{Przewrotny świat}

Trzecim wątkiem pojawiającym się jako wstęp do dalszych deliberacji na temat potrzeby spisania czynności prawnych jest przewrotny, upadty świat (mundus caducus), o którym opowiedziano w dwu dokumentach: wpierw w arendze dyplomu z Męki z 1255 r. dla mieszczan sieradzkich: [akt powierza się pismu] z racji że świat jest skazany na zniszczenie i podlega zmianom nieustannie przez różne sprawy ${ }^{31}$. O deprawacji i „złych czasach” mowa również w przytaczanej wyżej preambule dokumentu z Sadkowa z 1256 r. Zatem mianem znikomego i przewrotnego określono zarówno świat, jak i cały rodzaj ludzki, nadmieniając ponadto o tych przywarach jako specyfice czasów sobie współczesnych.

\subsubsection{Rzecz prawa - w niegodziwą}

W jednym dokumencie mowa o zaciemnianiu rzeczy pewnych, tak iż stają się niejasne dla potomnych ${ }^{32}$. Już w arendze dokumentu z Sadkowa z 1256 r. dla arcybiskupa gnieź-

29 M34 korr., Zgłowiączka, 11 VI 1253; KDP, t. 2, nr 60, s. 50: Et, ne procedente tempore de possessione... ab aliquibus possit ecclesia jnpediri...

30 M6 ar., Kruszwica, w grodzie, 13 I 1238; KDP, t. 2, nr 21, s. $16-17$ (z b1.): Contra temporis instabilitatem et fluxus rerum temporalium, que cum ipsius temporis decursu defluunt et uanescunt, utillimum est et catum, ut quod temporaliter agitur, testimonii seu littere memorie commendetur. (Analiza drugiego członu dalej).

31 M41 ar., Męka 1255: Quoniam mundus est caducus, et diuersis quotidie casibus variatur: idcirco necesse est actiones legitimas, quae memoria indigent, per scripti continentiam in noticiam transmitti posterorum.

32 Drugie stwierdzenie o tym, jak rzecz jasna zmienia się w ciemną, nierozumiałą, znajduje się w arendze dokumentu chcącego uchodzić za wystawiony we Włocławku 7 III 1231 (M1), zamieszczony w transumpcie Kazimierza Wielkiego: Quoniam longinquitate sepe fit temporis, quod res clara presentibus redditur obscura futuris et sic interdum decisa pululant, suscitantur sopita, et sepulta resurgunt; proinde prouidorum statuit auctoritas, vt ea, que geruntur in tempore, ne simul labantur cum tempore, testimonio litterarum confirmentur. Mitkowski jednakże wykazuje, iż musiał być to dyplom podrobiony (na podstawie innych przesłanek niż dawniej Ulanowski) i emenduje pierwotny dokument na wydany w Inowrocławiu 7 III 1246 r., sugerując ponadto, iż był zapewne o wiele krótszy od zachowanego podrobionego aktu. Na rozbiorze dokonanym przez owego badacza ucierpiała również przekazana arenga: w odtwarzanym możliwym brzmieniu oryginału Mitkowski pozbawia ją pierwszego członu, uważając tylko drugi za wiarygodny (proinde prouidorum... - confirmentur). $Z$ tegoż powodu nie uwzględniamy pierwszej części w głównym zrębie pracy. Zob. J. Mitkowski, Kancelaria..., s. 12-21, hipotetyczny wygląd pierwotnego dokumentu na s. 18. 
nieńskiego Pełki powiedziano, iż w czasach [nam] wspótczesnych rodzaj ludzki tak jest zdeprawowany, iż rzecz pewna, prawa, raczej w niegodziwa stara się obrócić, aby po części zmienić ja na korzystna dla siebie ${ }^{33}$.

\subsection{Konsekwencje niezapobiegliwości}

Motywy najważniejszych i najbardziej ryzykownych skutków, które mogą wystąpić, jeśli nie przedsięweźmie się odpowiednich środków dla utrwalenia i uwierzytelnienia decyzji świadectwem pisma, podjęto za pomocą czterech myśli. Są nimi zapomnienie, ściślej rozumiane jako wymazanie z pamięci (oblivio), wątpliwość (dubium i dubietas), złe pojmowanie rzeczy (calumpnia) oraz prawda (veritas). Po kolei zostaną teraz omówione.

\subsubsection{Zapomnienie i zapominanie}

Motyw zapomnienia jako wymazania z pamięci pewnych faktów czy wydarzeń pojawia się pięć razy: dwukrotnie w korroboracji, a trzykrotnie w arengach ${ }^{34}$. Najwcześniej mowa o zapomnieniu w korroboracji dyplomu wystawionego w grodzie w Kruszwicy 13 stycznia $1238 \mathrm{r}$. Wyrażono tam życzenie, aby rzeczy uczynione $w$ czasie $z$ powodu uptywu czasu, jak często się zdarza lub zwykto się zdarzać, nie pograżyty się w gtębi niepamięci ${ }^{35}$. Z kolei w korroboracji dokumentu dla biskupa włocławskiego Wolimira z roku 1255 sformułowano życzenie, aby opisane w akcie poświadczenia nie wpadty wśród potomnych w otchtań zapomnienia ${ }^{36}$. Dwukrotnie zatem posłużono się określeniem „otchłań niepamięci” w dokumentach, których powstanie dzieliło siedemnaście lat.

Jeśli chodzi o arengi, w dyplomie z Murzynna z roku 1248 dla wojewody łęczyckiego Spycigniewa, także w formie życzenia pada zdanie, aby [czyny, pisma] rzeczy zależnych od czasu nie popadty z powodu uptywu czasu w niepamię́ ludzi ${ }^{37}$. W dokumencie z Inowrocławia z 26 lipca 1252 r. dla Zakonu Krzyżackiego napisano o prawidłowości, iż wiele spośród czynów pociagnęto za soba niepewność [popadto w wątpliwość] i w konsekwencji pociąga to za sobą zapomnienie (z jednoczesną grą brzmieniową występujących

M42 ar., Sadków 1256; KDP, t. 2, nr 69, s. 58-59: ...in nostri temporis articulo humanum genus ita est deprauatum, quod rem certam pocius in sinistram, quam ad partem laborat diuertere meliorem...

34 M16 ar., Murzynno 1248; DKM, nr 11, s. 295 (wyd. II): acta rerum temporalium ne processu in oblivionem hominum temporis labantur; M30 ar., Inowrocław, 26 VII 1252; Preuss. UB, Bd. I, nr 260, s. 198200: Rerum gestarum multos in errorem traxit et trahit oblivio; M45 ar., Włocławek, 4 VIII 1257; UB Culm., nr 50, s. 34-35: acta mortalium delet oblivio.

35 M6 korr., Kruszwica, w grodzie, 13 I 1238 (przyp. 86): Verum ne processu temporis res acta in tempore, sicut plerumque contigit uel solet contigere, in aluo obliuionis demergatur...

36 M39 korr., 1255; DKM, nr 14, s. 188-189 (sugestia J. M., by wiersz 7 od dołu „custodes subditorum” emendować na „custodes silvarum”): Et ne protestaciones huiusmodi cadant apud posteros in abyssum obliuionis...

37 M16 ar.: acta rerum temporalium ne processu in oblivionem hominum temporis labantur... 
tam wyrazów $)^{38}$. W dyplomie z Włocławka również wystawionego dla Krzyżaków, tyle że 4 sierpnia 1257 r., wspomnienie o niepamięci pojawia się w pierwszym członie arengi: Lecz ponieważ czyny śmiertelnych gtadzi zapomnienie, trzeba je poświadczyć świadectwem pisma ${ }^{39}$. Zatem i w preambułach, i w koroboracjach wspomina się, iż prawidłowością losu jest, że rzeczy ludzkie bądź związane z czasem mogą popaść w niepamięć; ponadto pojawiają się wyrażenia, że inna przyczyna, jaką jest wątpliwość, pociąga za sobą niepamięć, która to może gładzić ludzkie czyny.

\subsubsection{Wątpliwość i powątpiewanie}

Samych formuł zawierających myśl o wątpliwości i powątpiewaniu odnotowałam dwanaście; w arengach pięć, w korroboracjach - siedem. Najbardziej czytelne będzie podzielenie ich na dubium, czyli powątpiewanie, oraz dubietas, czyli wątpliwość, stan niepewności. Poza tym pada w pewnym stopniu synonimiczne dla dubietas słowo error, które oznacza błąd, pomyłkę.

\section{Powątpiewanie}

Motyw wątpliwości przy pomocy słowa „powątpiewanie” (dubium) pada w trzech arengach $^{40}$. Najpierw w preambule dyplomu z Inowrocławia z 1250 r. dla klasztoru lądzkiego napisano, iż każdemu czynowi wspótczesnych zwykto towarzyszyć powatpiewa$n i e^{41}$. Fragmenty wyjęte $\mathrm{z}$ dwóch pozostałych areng brzmią prawie identycznie: pierwsza pochodzi z dokumentu z Kowala z 1251 r. dla biskupa krakowskiego Prandoty, druga zaś z aktu z Łęczycy z 3 sierpnia 1260 r. dla arcybiskupa gnieźnieńskiego Janusza. Powiedziano w nich, iż prawda czesto jest poddawana w wątpliwośs $c^{42}$.

Wyraz „powątpiewanie” (dubium) został zastosowany również w czterech korroboracjach. Za pierwszym razem w dokumencie z Kowala z 9 września 1251 r. dla opata sulejowskiego Piotra, potem zaś w dyplomie z 1257 r. dla Wolimira, biskupa włocławskiego, z Lubani z roku 1262 również dla tego hierarchy oraz z Inowrocławia z 14 września 1267 r. dla katedry włocławskiej. We wszystkich zwrotach ma miejsce życzenie $\mathrm{w}$ formie przeczącej: aby „nikt nie powątpiewał o dokonanej czynności”, aby $u$ nikogo nie śmiata powstać żadna wątpliwość, aby nie zostato wzbudzone [wzniecone] żadne po-

\footnotetext{
M30 ar. (zob. wcześniejsze przypisy): Rerum gestarum multos (!) in errorem traxit et trahit oblivio...

M45 ar.: Set quia acta mortalium delet oblivio...

Poza synonimicznym error, o którym na końcu.

41 M22 ar., Inowrocław 1250; KDW, t. I, nr 290, s. 252-253: factum omne modernorum haberi solet dubium... Podobnie brzmi fragment arengi podrobionego dokumentu chcącego uchodzić za dyplom wystawiony przez księcia Kazimierza w Kłobii w r. 1253: zob. M36 (podrobiony), Kłobia, 25 VII 1253; KDP, t. I, nr 42, s. 67-69: modernorum facta haberi solent dubia...

42 M25 ar., Kowal, 1251; KDKk, t. 1, nr 32, s. 40-41: ueritas plerumque in dubium reuocatur; M53 ar., Łęczyca, 3 VIII 1260; KDW, t. 1, nr 388, s. 343-344: veritas, falsitatis inimica, plurimum in dubium revocatur... Dokładniejsze omówienie przy fragmencie poświęconym motywowi prawdy.
} 
watpiewanie, żeby nad tym [postanowieniem] nie wytworzyto się żadne powatpiewanie oraz by nikomu w przysztości nie zrodzito się [ $w$ umyśle] niedowierzanie ${ }^{43}$.

\section{Wątpliwość}

Wątpliwość (dubietas) występuje w korroboracjach trzech dokumentów. W przypadku dyplomu z Kopaniny z 17 czerwca 1241 r. dla opata lądzkiego Jana uwierzytelnienie aktu zapowiedziano życzeniem, żeby nad tym [ustanowionymi decyzjami] w przysztości nie zostatpodniesiony [zarzucony] ciężar jakiejkolwiek watpliwościti ${ }^{4}$. Za to w korroboracji dokumentu z Kruszwicy z 19 sierpnia 1254 r. dla biskupa włocławskiego Wolimira ujęto sprawę w podobne słowa: aby nad tym [czynem] w przysztości nie wytonita się [nie wynurzyta] jakakolwiek watpliwośc ${ }^{45}$. Z kolei w dokumencie wystawionym w Inowrocławiu 7 marca 1246 r. wyrażono życzenie, żeby podjęte postanowienia ominąt ciężar wątpliwoścít ${ }^{46}$.

Niepewność, pomyłka

Za jedno jeszcze wspomnienie o wątpliwości można uznać wymieniony wyżej fragment arengi dokumentu z Inowrocławia z 26 lipca 1252 r. dla Zakonu Krzyżackiego, w którym pojawia się wyraz error: czyny wielu podawane sq w niepewność.

\subsection{Złe pojmowanie rzeczy}

Motyw złego pojmowania rzeczy (calumpnia) pojawia się w czterech arengach dokumentów z lat 1251, 1252, 1255 i 1261. Fragmenty wymienionych preambuł brzmią prawie tak samo: iż „złe rozumienie” spraw, wydarzeń, zwykto dotykać czynów ludzkich. Jest to człon zdania pisany podobnie albo niemal identycznie. Jedynie w preambule dokumentu z Kowala z 9 września 1251 r. dla cystersów sulejowskich zastosowano inną składnię niż w pozostałych przypadkach, zaś w dyplomie z 25 maja 1252 r. spełniającym prośby biskupa pruskiego Chrystiana użyto innego czasownika; w arengach dokumentów z Kramska z 15 sierpnia 1255 r. dla biskupa włocławskiego Wolimira oraz z 6 lutego 1261 r. z Kazimierza dla opata cysterskiego Piotra fragment brzmi tak samo ${ }^{47}$.

43 M24 korr., Kowal, 9 IX 1251; KDP, t. I, nr 37, s. 58-60.: ne cuiquam dubium aliquot... valeat suboriri; M49 korr., 1257; DKM, nr 16, s. 190-191: ne.. dubium aliquod suscitetur; M58 korr., Lubanie 1262; KDP, t. II, nr 452, s. 615-616: ne super hoc dubium aliquod generetur; M67 korr., (interpolowany?) Inowrocław, 14 XII 1267; DKM, nr 37, s. 212: ne... alicui in posterum dubium oriatur...

44 M9, Kopanina, 17 VI 1241; KDW, t. 1, nr 228, s. 191-192: Et ne super hoc scrupulus alicuius dubietatis in posterum oriatur...

45 M37 korr., Kruszwica, 19 VIII 1254; KDP, t. 2, nr 63, s. 51-52: ne super hoc in posterum aliqua dubietas emergat...

46 M1 korr. (zob. wcześniejsze przypisy): Vt... confirmacio scrupulum dubietatis amittat...; za emendacją i hipotetycznym odtworzeniem jego brzmienia przez Mitkowskiego (J. Mitkowski, Kancelaria..., s. 18).

47 Dla porównania: M24, M28, M38, M54. W ar. M24: Quoniam decursu temporis calumpnia consuevit actibus hominum novercari, litterarum testimonia et testium subscripcio sollerter hoc debent precavere. 


\subsection{Czas a stałość}

\subsubsection{Trwałość}

Wszystkich stwierdzeń zawierających motyw trwałości (inconcussio, firmitas) w dyplomach księcia kujawsko-łęczyckiego występuje dwadzieścia jeden, z czego trzy w narracjach, cztery w dyspozycjach, trzynaście w korroboracjach ijeden w maledykcji. Pojawiają się one w dokumentach przez okres całego panowania Kazimierza Konradowica. Te zaś rozdzielić można ze względu na zastosowane słownictwo: „nietknięty” (inconcussus); „bez uszczerbku” (sine concussione); „trwałość" i „trwały” (firmitas i firmus); „nienaruszony”, "nienaruszenie” (inviolabilis, inviolabiliter, inconvulse, incommutabilis); „trwały” (ratus); „nietknięty” (illibatus); „chcielibyśmy umocnić” (fecimus communiri).

\subsubsection{Uwiecznianie}

Wszystkich zwrotów mówiących o uwiecznianiu podjętych decyzji, chęci, aby przetrwały one w sposób nienaruszony przez pokolenia albo by zostały przedłużone przez potomnych w dyplomach jest ogółem dwadzieścia jeden, z czego czternaście w korroboracjach, cztery w arengach, po jednym za to w promulgacji, narracji i dyspozycji. Najczęściej łączono słowa permaneat z perpetuo albo in perpetuum, czyli „niech trwa wiecznie” lub „na wieki”, zaraz później perpetuari i perhennentur, czyli „zostawać uwiecznionym". Kolejne to połączenie omni aevo, inviolabilis/rata et inconcussa oraz permaneat/perseveret - „po wszystkie wieki”, „nienaruszone, trwałe” i „przetrwa”. Poza tym dwukrotnie padają określenia „późniejszy czas”, raz „na wieczność” i raz w kontekście chwały książęcej, „by nie miała ona końca”.

\subsection{Cel główny spisania i uwierzytelnienia dokumentów}

\subsubsection{Prawda}

Zwrotów zawierających myśl o veritas, czyli o prawdzie, jest ogółem osiem; padają $\mathrm{w}$ czterech korroboracjach i w trzech arengach, $\mathrm{z}$ tego $\mathrm{w}$ jednej dwukrotnie. W korroboracjach motyw prawdy został wprowadzony za pomocą zwrotów, iż z racji, że często ginie kopia dowodu i prawda jest [tym sposobem] zaciemniana, dokument musi zostać uwierzytelniony. Taki zwrot pada w korroboracjach dokumentów z Przypustu z roku 1247 dla braci Recława i Marcina, z 25 maja 1252 r. dla cystersów sulejowskich oraz z Łęczycy z 3 sierpnia 1260 r. dla arcybiskupa gnieźnieńskiego Janusza i z Kazimierza z 6 lutego 1261 r. znów dla zakonników w Sulejowie. Różnice występują tylko w synonimicznych czasownikach ${ }^{48}$.

Spośród sformułowań o prawdzie znajdujących się w preambułach jedno to erudycyjny opis w dyplomie wystawionym dla arcybiskupa Pełki w Sadkowie w roku 1256

48 M13, M28, M54 korr.: occultatur, M54: obscuratur... 
o tym, jak zagrzewającemu ogienkowi prawdy przeciwdziała ochtadzajace źródetko fat$s z u^{49}$. Kolejne dwa przykłady omawianego motywu występujące w arengach to stwierdzenia w dokumencie z Kowala z roku 1251 dla biskupa krakowskiego Prandoty, tudzież z aktu z Łęczycy z 3 sierpnia 1260 r. dla arcybiskupa gnieźnieńskiego Janusza, iż prawda często jest poddawana [dosłownie: „ponownie przyzywana”] powątpiewaniu. W przypadku późniejszego dyplomu prawdę dookreślono jako „przyjaciółkę nieprawdy"50. Ostatni raz omawiany wątek można zauważyć w dyplomie z Kowala 1251 r. w interesująco skomponowanym życzeniu, żeby prawda trwała „aż do wiecznej przyszłości” ${ }^{2}$.

\subsubsection{Pamięć}

Zwrotów zawierających odwołanie do pamięci (memoria) w dokumentach Kazimierza Konradowica odnalazłam 16, z czego aż dziesięć zamieszczono w arengach, w promulgacji jedną, w korroboracjach zaś - pozostałe pięć.

Co do preambuł ze słowem „pamięć”, można wyróżnić aż pięć dokładniejszych rodzajów zwrotów, jakimi posługiwali się kanceliści Konradowica. Do pierwszego należą trzy dyplomy zawierające stwierdzenie, aby czyny nie uchodzity z ludzkiej pamię$\mathrm{ci}^{52}$. W drugiej grupie zawiera się gra słów pamięć-litery (pismo), memoria-litterae, tj. o pamięci, którą przechowuje pismo. W dokumentach księcia Kazimierza raz stworzono określenie "pamięć liter” (tłumaczenie dosłowne), memoria literarum (w dyplomie z Dankowa z 30 czerwca 1238 r. dla klasztoru w Strzelnie). Trzy razy mowa o „pamięci litery", littere memoria (w dokumentach z Kopaniny z 17 czerwca 1241 r. dla zgromadzenia lądzkiego, z Sompolna z 7 czerwca 1242 r. dla cystersów sulejowskich i w dyplomie z Kłobi z 1250 r. dla ich opata) ${ }^{53}$. Trzeci rodzaj stwierdzeń, charakterystyczny dla dwu dokumentów księcia kujawsko-łęczyckiego, to zwrot o przechowywaniu przez pamięć czynów prawnych podległych czasowi: memoria indigens ( $\mathrm{w}$ dyplomach z Kramska z roku 1251 dla cystersów w Lądzie, z 25 maja 1252 r. dla cystersów w Sulejowie i z Męki z roku 1255 dla dwóch mieszczan sieradzkich) ${ }^{54}$.

Co do odwołań do pamięci w promulgacjach, pojawia się ono jedynie w dokumencie z Dobrzynia z 29 września 1252 r. dla grodów biskupstwa płockiego za pomocą niepowtórzonego nigdzie indziej zwrotu: aby wystawca nie byt zapomniany [przez potomnych $]^{55}$. W korroboracji zwroty o pamięci mają charakter prawie jednolity. Jeden

\footnotetext{
M42 ar. Veritatis igniculo refrigescente, falsitatis autem curriculo inualescente...

50 M25 ar. Quoniam propter tractum temporis longeui sepius sufficencia deficit probacionis, et sic ueritas plerumque in dubium reuocatur; M53 ar. [jak wyżej] longevi... veritas, falsitatis inimica, plurimum in dubium revocatur...

51 M25 ar.: ut sic ueritas loco sui tentoij dilatato, funiculos memorie amodernis protendat usque ad sempiternam posteritatem...

52 M3 ar.: ne a memoria recesserint; M17a, M20: ne a memoria euanescat...

53 M8 ar.: memoria literarum; littere memoria: M9 ar. vivacis, M10 ar.: testimonialis, M21 ar.: testimonialis.

54 M26 ar., M28 ar., M41 ar.: memoria indigens.

55 M32 prom.: non simus immemores.
} 
zwrot brzmi: „dla pamięci czynów”, zaś pozostałe cztery - na rzeczy wieczna pamięć, pamiatke $e^{56}$.

Motywy memoratywne dokumentów księcia kujawsko-łęczyckiego można podzielić na te, w których: 1) podjęto problem znikomości świata i chwiejności czasu; 2) położono nacisk na konsekwencje ludzkiej niezapobiegliwości; 3) rozważa się zależność między czasem a stałością; 4) zauważyć da się coś na kształt dociekań, jaka główna myśl jest powodem, a jaka celem spisania i uwierzytelnienia dyplomów.

\section{PODSUMOWANIE}

Z przedstawionych motywów memoratywnych dokumentów Kazimierza Konradowica wyłania się obraz świata znikomego, nietrwałego, w którym wszystko, co ziemskie, skazane jest na upadek bądź zniszczenie. Zauważalna jest jednak przede wszystkim inna, ważniejsza, ciągle się przewijająca konstatacja: że to czas jest przyczyną destrukcji wszystkiego, co mu podległe, zatem wszystkiego, co ze świata. Analogicznie, także ludzie, którzy dążą tylko do spraw ziemskich, nie potrafią zabezpieczyć podjętych decyzji i nie pozwalają, aby przetrwały dłużej od innych rzeczy podlegających upływowi czasu. $\mathrm{Z}$ tego powodu przed niszczącą mocą czasu mogą uchronić się te akcje prawne, których wystawca patrzy dalej i wyżej niż pozostali: musi zapatrzeć się on na świat pozaziemski, na niebiańską rzeczywistość. Pragnąc naśladować Boga, musi działać w taki sposób, aby jego dzieła trwały przez wieki. Trzeba zatem, aby zadbał zarówno o staranne spisanie, jak i uwierzytelnienie podjętych przez siebie czynności prawnych. Wówczas przetrwa pamięć o podjętych przezeń decyzjach, ale także o nim, o czym nie napisano wprost w omawianych formułach dokumentów.

$\mathrm{Z}$ pozostałych motywów, których w tym artykule nie omówiono, filozoficznych, majestatycznych i religijnych, wyłania się wyobrażenie postaci, która przeciwstawia się wspomnianym wyżej niszczącym kolejom losu i podejmuje czyny trwałe; wyobrażenie jest nakreślone w sposób wysublimowany, ale wystarczająco czytelny dla osób o duchowości i subtelności XIII stulecia. Pamiętać należy oczywiście o wąskim gronie odbiorców, jakie stanowiła elita intelektualna, duchowna i świecka, będąca pod jurysdykcją tego władcy bądź w zasięgu jego oddziaływania. Niemniej właśnie ci ludzie mogli udzielać poparcia monarsze i jego planom.

Po wczytaniu się w dyplomy wystawione przez księcia kujawsko-łęczyckiego dostrzec można wysokie przesiąknięcie treściami ideowymi całej warstwy tekstowej, jak również ich różnorodność. Zadaniem tej pracy było przedstawienie części treści ideowych, którymi są motywy memoratywne. W przyszłości chciałabym zaprezentować uszeregowanie pozostałych motywów. Artykuł wpisuje się w szerszy kontekst badań nad kancelariami piastowskimi doby rozbicia dzielnicowego, podejmuje jednak temat

56 M20 korr.: In memoriam gestorum; (M40, M44, M53, M54) korr.: in rei perpetuam memoriam. Zwrot ten pada również w podrobionym dokumencie chcącym uchodzić za wystawiony w Zgierzu... (M47); Szacherska w odtworzonym przez siebie dyplomie nie uwzględnia wspomnianego sformułowania za autentyczne w tym przypadku. Zob. S. M. Szacherska, $Z$ dziejów..., s. 1-23. 
nieopracowany dotychczas, jakim są motywy ideowe występujące w dokumentach księcia Kazimierza. Moim zdaniem dopiero omówienie wszystkich treści i zbadanie ich w kontekście odpowiedzialnego za nie personelu kancelaryjnego oraz dojrzałości dokumentów wygotowanych przez równoległe tej bądź wcześniejsze kancelarie piastowskie i europejskie pozwoli na przedstawienie wizji całościowej, na którą czeka polska nauka.

\author{
Wykaz skrótów i akronimów \\ DKM - Dokumenty kujawsko-mazowieckie \\ KDKk - Kodeks Dyplomatyczny Katedry Krakowskiejs. Wactawa \\ KDP - Kodeks Dyplomatyczny Polski \\ KDW - Kodeks Dyplomatyczny Wielkopolski \\ KDM - Kodeks Dyplomatyczny Matopolski \\ KDMaz - Kodeks Dyplomatyczny Księstwa Mazowieckiego \\ Pommerell. UB - Pommerellisches Urkundenbuch \\ Preuss. UB - Preussisches Urkundenbuch \\ UB Culm. - Urkundenbuch des Bisthums Culm
}

\title{
Wykaz regestów (miejsca wydania - za Józefem Mitkowskim)
}

M1 (przerob. w XIV w.), Inowrocław, 7 III 1231; DKM, nr 8, s.121-122.

M2 (antedatowany) Strzelce, 6 I 1233; Preuss. UB, Bd. 1, nr 94, s. 70-71.

M3 Kruszwica, 1233; KDP, t. 2, nr 14, s. 11-12.

M4 1234; DKM, nr 9, s. 123.

M5 1235; KDP, t. II, nr 439, s. 593.

M6 Kruszwica, w grodzie, 13 I 1238; KDP, t. 2, nr 21, s. 16-17 (z bł.).

M7 Pyszkowo, 29 VI 1238; Preuss. UB., Bd. 1, nr 130, s. $98-99$ (z bł.).

M8 Danków, 30 VI 1238; DKM, nr 10, s. 123-124.

M9 Kopanina, 17 VI 1241; KDW, t. 1, nr 228, s. 191-192.

M10 Sompolno, 7 VI 1242; DKM, nr 9, s. 179.

M11 Inowrocław, 5 III 1246; Pommerell. UB, nr 92, s. 80.

M12 Włocławek, 7 III 1246; DKM, nr 11, s. 124-125.

M12a Włocławek, 7 III 1246; tekst zrekonstruowany: J. Mitkowski, Kancelaria Kazimierza Konradowica księcia kujawsko-tęczyckiego, 1968, część I, rozdział 1, s. 18.

M13 Przypust, 1247; DKM, nr 11, s. 183 (z bł.).

M14 Kowal, 6 V 1248; KDP, t. II, nr 41, s. 40.

M15 Zgierz, 1248; DKM, nr 12, s. 184.

M16 Murzynno 1248; DKM, nr 11, s. 295 (wyd. II).

(M17) I (zrekonstruowany autentyk) Kruszwica, 24 VI 1249; J. Mitkowski, Kancelaria Kazimierza Konradowica księcia kujawsko-tęczyckiego, 1968, część I, rozdział 2, s. 26-27.

M17 II (podrobiony) Kruszwica, 24 VI 1249; DKM, nr 12, s. 125-126. 
M17a Inowłódz na wiecu, XII 1249; K. Maleczyński, Dwa nieznane dokumenty, „Kwartalnik Historyczny" 1924, t. XXXVIII, s. 456-459.

M18 Raciążek, 7-12 I 1250; KDP, t. 2, nr 45, s. 42-43.

M18a Kłobia (Closa), 25 VII 1250; K. Maleczyński, Kilka nieznanych dokumentów z XIII w. przeważnie z archiwów poznańskich, „Rocznik Historyczny” 1926, t. 2, nr 3, s. 194.

M19 Kłobia, 10 VIII 1250; KDP, t. 2, nr 46, s. 43.

M20 Sieradz, w klasztorze dominikanów, 6 X 1250; DKM, nr 13, s. 184-188 (z or-u).

M21 Kłobia, 1250; KDP, t. 3, nr 27, s. 54-55.

M22 Inowrocław, 1250; KDW, t. 1, nr 290, s. 252-253.

M23 1250; KDP, t. II, nr 44, s. 41-42.

M24 Kowal, 9 IX 1251; KDP, t. 1, nr 37, s. 58-60.

M25 Kowal, 1251; KDKk, t. 1, nr 32, s. 40-41.

M26 Kramsko, 1251; KDP, t. 1, nr 36, s. 56-58.

M27 Kowal, 24 III 1252; KDP, t. 2, nr 52, s. 45.

M28 25 V 1252; KDW, t. I, nr 304, s. 270-271 (z or-u).

M29 Kłobia, 30 VI 1252; KDP, t. 2, nr 443, s. 598-599 (z bł.).

M30 Inowrocław, 26 VII 1252; Preuss. UB, Bd. 1, nr 260, s. 198-200.

M31 Dobrzyń, 29 IX 1252; KDP, t. 2, nr 44, s. 600.

M32 Dobrzyń, 29 IX 1252; DKM, nr 11, s. 157-158 (z or-u).

M33 1252; Pommerell. UB, nr 141, s. 121-122.

M34 Zgłowiączka, 11 VI 1253; KDP, t. 2, nr 60, s. 50.

M35 Kłobia, 7 VII 1253; KDP, t. 2, nr 34, s. 36-38.

M36 (podrobiony) Kłobia, 25 VII 1253; KDP, t. 1, nr 42, s. 67-69.

M37 Kruszwica, 19 VIII 1254; KDP, t. 2, nr 63 (błąd zecerski: XLIII), s. 51-52.

M38 Kramsko, 15 VIII 1255; KDP, t. 2, nr 68, s. 56-58.

M39 1255; DKM, nr 14, s. 188-189 (sugestia J. M., by słowa wiersza siódmego od dołu custodes subditorum emendować na custodes silvarum).

M40 Inowrocław, 1255; Preuss. UB, Bd. 1, nr 303A, s. 224-226 (z or-u 1); DKM, nr 15, s. $189-190$ (z or-u 2).

M41 Męka (Manka), 1255; KDP, t. 2, nr 64, s. 53-55.

M42 Sadkow, 1256; KDP, t. 2, nr 69, s. 58-59.

M43 2 I 1257; KDP, t. 2, nr 446, s. 605.

M44 3 V 1257; KDM, t. 1, nr 48, s. 57-58.

M45 Włocławek, 4 VIII 1257; UB Culm., nr 50, s. 34-35.

M46 Nad rzeką Wel, 16 IX 1257; UB Culm. I, nr 51, s. 36.

M47 (podrobiony) Zgierz, 10 XI 1257; DKM, nr 19, s. 192-193.

M48 (autentyk interpolowany) Zgierz, 10 XI 1257; S. M. Szacherska, Z dziejów kancelarii książą kujawskich, „Studia Źródłoznawcze” 1960, t. 5, s. 19-21.

M49 1257; DKM, nr 16, s. 190-191.

M50 Inowrocław, 1257; DKM, nr 18, s. 192.

M51 [Inowrocław], 2 I 1258; KDP, t. 2, nr 449, s. 611.

M52 Tuszyn, 13 VI 1260; KDP, t. 1, nr 48, s. 83-84. 
M53 Łęczyca, 3 VIII 1260; KDW, t. 1, nr 388, s. 343-344.

M54 Kazimierz, 6 II 1261; KDP, t. 1, nr 49, s. 84-86.

M55 1261; DKM, nr 24, s. 197-198.

M56 Lubanie, [13 VI] 1262; KDP, t. 2, nr 454, s. 617.

M57 Inowrocław, 4 X 1262; DKM, nr 29, s. 201-202 (błędnie podane imię opata).

M58 Lubanie, 1262; KDP, t. 2, nr 452, s. 615-616.

M59 Kowal, 1262; KDP, t. 2, nr 453, s. 616 (z bł.).

M60 Kowal, 1262; KDP, t. 2, nr 33, s. 35-36.

M61 Inowrocław (przed 19 II) 1263; Pommerell. UB, nr 198, s. 166-167.

M62 Dobrzyń, 13 VI 1263; KDMaz, nr 31, s. 23 (z bł.).

M63 Włocławek, 13 IV 1266; KDP, t. 2, nr 89, s. 70-71.

M64 Włocławek, 13 IV 1266; KDP, t. 2, nr 90, s. 72-74.

M65 1266; DKM, nr 35, s. 205-206.

M66 Inowrocław, 19 IX 1267; KDW, t. 1, nr 428, s. 379.

M67 (interpolowany?) Inowrocław, 14 XII 1267; DKM, nr 37, s. 212.

M68 Inowrocław, 14 XII [1267]; KDP, t. 2, nr 96, s. 81-82 (błędna data roczna 1268).

\section{BIBLIOGRAFIA}

\section{Literatura źródłowa:}

- Dokumenty kujawskie i mazowieckie, wyd. i zebr. B. Ulanowski, Kraków 1887.

- Kodeks dyplomatyczny katedry krakowskiej ś. Wactawa, wyd. F. Piekosiński, cz. 1, Kraków 1874.

- Kodeks dyplomatyczny Matopolski, wyd. F. Piekosiński, t. 1, Kraków 1876.

- Kodeks dyplomatyczny Polski, wyd. L. Rzyszczewski, A. Muczkowski, przypisami opatrzył A. Helcel, t. 1, Warszawa 1847.

- Kodeks dyplomatyczny Polski, wyd. L. Rzyszczewski i A. Muczkowski, t. 2, cz. 1, Warszawa 1848.

- Kodeks dyplomatyczny Wielkopolski, t. 1, Poznań 1877.

- Maleczyński K., Dwa nieznane dokumenty jędrzejowskie z XIII w., „Kwartalnik Historyczny" 1924 , t. 38.

- Maleczyński K., Kilka nieznanych dokumentów, „Kwartalnik Historyczny” 1926, t. 40.

- Pommerellisches Urkundenbuch, hrsg. von M. Perlbach, Danzig 1882.

- Preussisches Urkundenbuch, Bd. 1: Die Bildung des Ordensstaats, Erste Hälfte, hrsg. von R. Philippi, in Verbindung mit C. P. Wölky, Königsberg 1882.

- Szacherska S. M., Z dziejów kancelarii książąt kujawskich, „Studia Źródłoznawcze” 1960 , t. 5.

- Urkundenbuch des Bisthums Culm, brb. von C. P. Wölky, Th. I.: Das Bisthum Culm unter dem Deutschen Orden. 1243-1466, Danzig 1885.

- Urkundenbuch zurLandes-undRechtsgeschichte des Herzogthums Westfalen, von J. S. Seibertz, Bd. I: 799-1300, Arnsberg 1839. 


\section{Literatura pomocnicza:}

- monografie i opracowania:

- Adamska A., Arengi w dokumentach Wtadystawa Eokietka. Formy i funkcje, Kraków 1999.

- Balzer O., Genealogia Piastów, Kraków 1895.

- Barret S., Grévin B., Regalis excellentia. Les préambules des actes des rois de France au XIV e siècle (1300-1380), Paris 2014.

- Dworzaczek W., Genealogia, Warszawa 1959.

- Fichtenau H., Arenga. Spätantike und Mittelalter im Spiegel von Urkundenformeln, GrazKöln 1957.

- Fichtenau H., Beiträge zur Mediävistik. A. Ausgewählte Aufsätze. Allgemeine Geschichte, Bd. II, Stuttgart 1977.

- Kantorowicz E., Dwa ciata króla. Studium ze średniowiecznej teologii politycznej, tłum. M. Michalski, A. Krawiec, Warszawa 2007.

- Książe Kazimierz Konradowic i Kujawy jego czasów, red. D. Karczewski, Kraków 2017, http://dx.doi.org/10.12775/KLIO.2018.023.

- Kuraś S., Przywileje prawa niemieckiego miast $i$ wsi matopolskich XIV-XV wieku, Wrocław-Warszawa 1971.

- Maleczyński K., Zarys dyplomatyki polskiej wieków średnich, Wrocław 1951.

- Michałowski R., Princeps fundator. Studium z dziejów kultury politycznej w Polsce X-XIII wieku, Warszawa 1993.

- Mitkowski J., Kancelaria Kazimierza Konradowica księcia kujawsko-tęczyckiego (1233-1267), Wrocław 1968.

- Murphy J., Rhetoric in the Middle Ages, Berkeley-Los Angeles-London 1974.

- prace zbiorowe:

- Dyplomatyka staropolska, red. T. Jurek, Warszawa 2015.

- Guyotjeannin O., Pycke J., Tock B.-M., Diplomatique médiévale, Paris 1993.

- rozdziały w pracach zbiorowych:

- Grabowski J., Kancelarie ksiązęce na Mazowszu (XIII-XVI w.). Stan badań i perspektywy badawcze, [w:] Belliculum diplomaticum II Thorunense. Kancelarie wtadców na ziemiach polskich w'średniowieczu i czasach nowożytnych na tle porównawczym, red. W. Chorążyczewski, J. Tandecki, Torun 2007, s. 153-169.

- Korolko M., Z badań nad retorycznościa polskich kronik średniowiecznych (ethopoiiasermocinatio-fikcyjna mowa), [w:] Literatura i kultura późnego średniowiecza w Polsce, red. T. Michałowska, Warszawa 1993, s. 125-139.

- Korta W., Rola kulturalna średniowiecznej kancelarii, [w:] Studia z dziejów kultury i ideologii. Ofiarowane Ewie Maleczyńskiej w 50. rocznice pracy dydaktycznej i naukowej, WrocławWarszawa-Kraków 1968, s. 63-78.

- Perzanowski Z., Ze studiów nad arenga dokumentów Kazimierza Wielkiego, [w:] Historia i archiwistyka. Ksiega pamiątkowa ku czci prof. Andrzeja Tomczaka, Toruń-Warszawa 1992, s. 16-17. 
- Tock B.-M., Les textes diplomatixes, des médias au Moyen Âge?, [w:] Le rôle des médias à travers l'histoire, textes réunis et publiés par M. Serwański, Poznań 1995, s. 62-84.

- Vulliez C., L'apprentissage de la rédaction des documents diplomatiques à travers l' ars dictaminis français (et spécialement ligérien) du XIIe siècle, [w:] Cancelleria e cultura nel Medio Evo. Comunicazioni presentate nelle sedute della Commission internazional de diplomatique, Città del Vaticano 1990, s. 76-95.

- Worstbrock J., Die Antikenrezeption in der mittelalterlichen und der bumanistischen Ars Dictandi, [w:] Die Rezeption der Antike. Zum Problem de Kontinuität zwischen Mittelalter und Renaissance, hrsg. von A. Buck, Hamburg 1981, s. 15-24.

- artykuły w czasopismach naukowych:

- Jurek T., Stanowisko dokumentu w średniowiecznej Polsce, „Studia Źródłoznawcze” 2002, t. 40.

- Powierski J., Wydzielenie Kujaw Kazimierzowi Konradowicowi (potowa 1230 r.), „Rocznik Łódzki” 1993, t. 40.

- Sikora F., Janusz, kanclerz arcybiskupa Petki i księcia Kazimierza Konradowica (1232-1252 i 1252/53-1258), „Nasza Przeszłość” 1966, t. 24.

- Szacherska S. M., Z dziejów kancelarii książat kujawskich w XIII wieku. Dwa nieznane dokumenty szpetalskie, „Studia Źródłoznawcze” 1960, t. 5.

- Zimmermann M., Protocoles et Préambules dans les documents Catalans du Xe au XII siècle. Évolution diplomatique et signification spirituelle. Les Protocoles, „Mélanges de la Casa de Velázquez" 1974, t. 10.

Gertruda DRELICHARZ, studentka studiów II stopnia na kierunku historycznym o specjalizacji dziedzictwo historyczne i edytorstwo źródeł na Uniwersytecie Jagiellońskim. Interesuje się dyplomatyką oraz paleografią i sfragistyką, zwłaszcza problematyką kształtowania się kancelarii książęcych w Polsce dzielnicowej u progu kształtowania się idei zjednoczenia Królestwa Polskiego. 